\title{
Enabling Environment for Inclusive Horticultural Value Chain for Smallholders in Gauteng Province, South Africa
}

\author{
Portia Ndou ${ }^{1}$, Bridget Taruvinga ${ }^{1}$, Christian P. du Plooy ${ }^{1}$, Tshililo Ramusandiwa ${ }^{1} \&$ Michael Mokwala $^{2}$ \\ ${ }^{1}$ Agricultural Research Council-Vegetables and Ornamental Plants (ARC-VOP), Crop Science Division, Pretoria, \\ South Africa \\ ${ }^{2}$ Gauteng Department of Agriculture and Rural Development (GDARD), South Africa \\ Correspondence: Portia Ndou, Agricultural Research Council-Vegetables and Ornamental Plants (ARC-VOP), \\ Crop Science Division, Private Bag X293, Pretoria 0001, South Africa. Tel: 27-12-808-8000. E-mail: \\ ndoup@arc.agric.za
}

Received: September 22, 2020

Accepted: December 1, 2020

Online Published: January 15, 2021

doi:10.5539/jas.v13n2p66

URL: https://doi.org/10.5539/jas.v13n2p66

\begin{abstract}
The purpose of this study was to investigate the enabling environment within which smallholder farmers operate amidst the uneven playing field in the agricultural sector and the stringent demands of the consumer driven market. Most of the smallholder farmers utilise informal vegetable markets and these offer higher prices for the leafy vegetables. The study is based on data collected from 56 smallholder vegetable producers in Gauteng Province of South Africa. The study unveiled that the business environment has many challenges for the smallholder to competitively function in formal marketing channels, including poor upstream and downstream linkages and access to finance and technology. Access to inputs is a limiting factor to productivity with almost $41.7 \%$ of the farmers depending of government input handouts. The results of the logistic regression analysis shows a positive relationship between the choice of most utilised market and age, level of education, established arrangement with certain markets and sources of information on markets. This study concludes that there is need for multi-stakeholder engagements including organisations already working with smallholder farmers in order to ensure that there is no overlap of support services and hence indirectly ensuring wider coverage of farmer support. Both upstream and downstream linkages need to be promoted and this needs the intervention of the government through the support of organisations such as the national Department of Agriculture.
\end{abstract}

Keywords: enabling environment, value chain, inclusive, smallholder farmers

\section{Introduction}

The globalisation of the agribusiness sector has shifted the focus from production-oriented approach to market or consumer-driven value chain operations. This has seriously affected smallholder agriculture and rural livelihoods globally (Vorley et al., 2007). In essence, global markets are characterised by vertical coordination, high demand on innovation, high quality products and traceability. A combination of these demands puts strains on producers, with the hardest impacts felt by the smallholders. While the smallholders form the structural backbone of the rural economy (von Loeper et al., 2018), their participation in formal markets is smothered by competition from larger and successively growing national producers as well as those from other countries through increased imports (Louw et al., 2007; Muchopa, 2013). Consequently, today's competitive global markets have seen limited activity by smallholders within the mainstream value chain, and in some instances they are completely excluded. Farmers and policy makers thus remain challenged to continuously adapt to the new demands by the markets (Konig et al., 2013).

Mainly smallholders engage in growing horticultural crops for food security. However, an increasing number of the smallholders are now producing for the market, where some market their sellable excess. Whilst smallholders seek to participate in the high value chain, they continue to suffer exclusion. Some of the critical elements that contribute towards their exclusion in the mainstream value chain include the unaccommodating behaviour of the other value chain actors, the environment within which these players operate as well as the availability and accessibility of service providers. The actors have varying power leverages and inherent advantages that may render the playfield uneven. Figure 1 presents the categorisation of these components. Of critical importance to 
this study is the business environment within which the smallholders do business, which either works in the favour of all the players or otherwise.

Considerations

Criteria Chosen

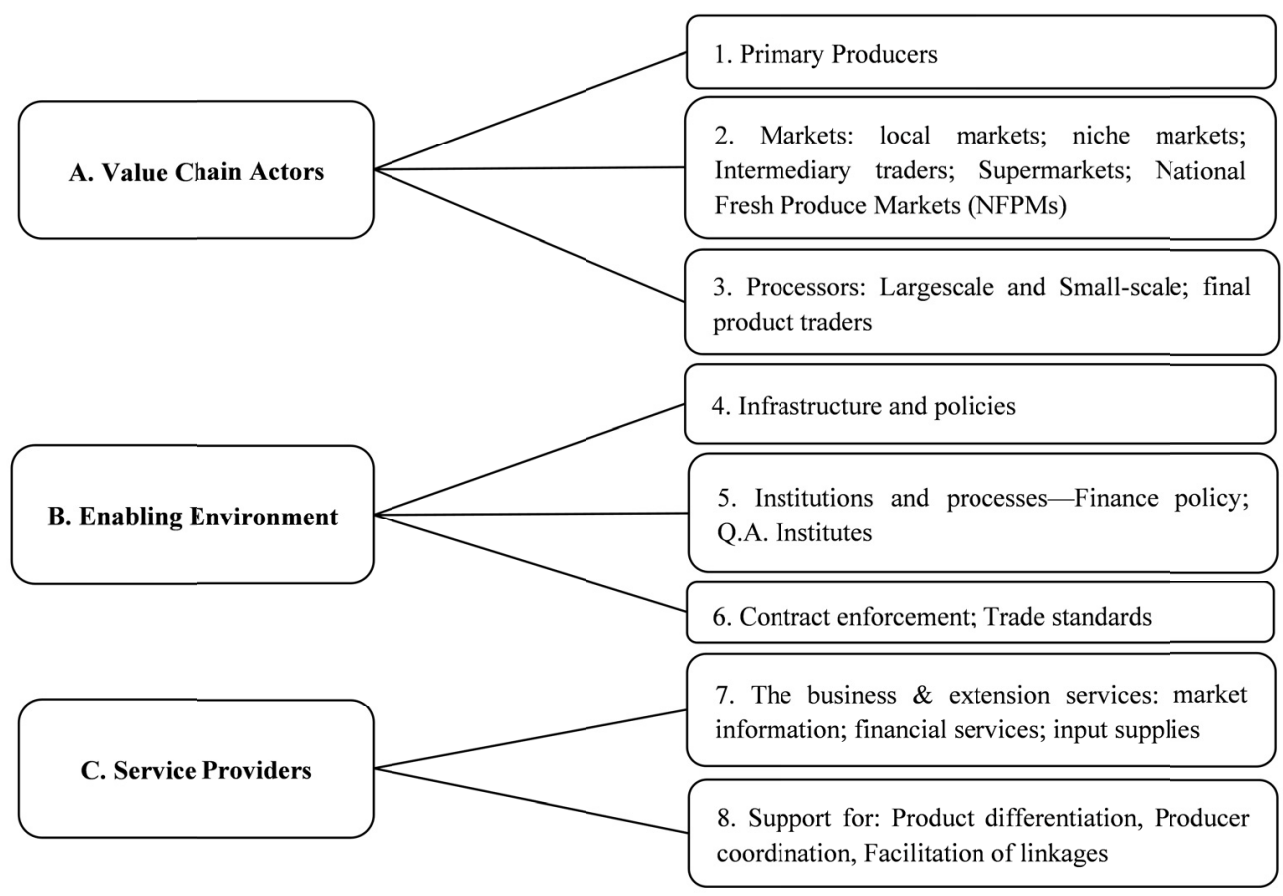

Figure 1. The three interlinked components of the market map (Neven, 2015)

The enabling business environment is defined as collections of policies, institutions, support services and other conditions that collectively shape the costs and risks of engaging in business (Christy et al., 2009). The enabling environment thus, entails farmers' needs (infrastructure, inputs, credit and marketing), laws or policies and regulations, public infrastructure, contract enforcement, both national and global trade standards, institutions and social dynamics (Feed the Future, 2017; Neven, 2015). The enabling environment is important for purposes of protecting health and safety, levelling the playing field, expanding production and market potential as well as promoting resilience. Consequently, these have a bearing on the competitiveness of an enterprise and its value creation abilities and the ability to thrive. In essence, economic development is moored on an enabling environment where the presence, interaction and capacity of different institutions, policies and services promote growth and operation at both domestic and international levels. However, vested interests, limited institutional capacity, sequencing and evolution of the enabling environment over time, timeframe for reform and metrics and attribution may hinder meaningful enabling environment reforms (Feed the Future, 2017).

The South African agricultural industry and its interrelated industries have been ushered with many policies and strategies that aim to promote investments in agro-enterprises and develop agro-based value chains (Konig et al., 2013). While they are of paramount importance, policies on their own cannot suffice the conducive environment that enables an inclusive environment for equal participation in the high value chain. Rather, some form of complimentary action is needed. For instance, the availability of good quality infrastructure is an invaluable compliment to agriculture and macro-economic policies in the search to raise agricultural productivity and the consequent benefits that include a reduction in food prices, poverty reduction and improved no-farm labour opportunities (Llanto, 2012). Improved access to finance informs farmers' decisions to invest and engage in agricultural production. In essence, access to finance eases the ability of the farmers to match their needs and ability to adopt advanced or better technologies as well as managing risks (Karlan et al., 2012a). In many instances, the challenge of credit availability is either a missing or an imperfect service to the smallholders (von Loeper et al., 2016). Banks have a mandate to assess situations with low risk factors, with repayment ability and affordability of the loan. However, the smallholders are deficient of these qualities and any support of a loan in the face of the smallholder farmer attributes would be reckless lending and is prohibited by the South African 
Credit Act. In addition to the foregoing notion, markets also fail to provide solutions to the challenges of financing.

The ability of the value chain player to cope with the environmental shocks is very crucial regardless of the point at which the actor in located within the value chain. For the primary agricultural producers, shocks in production are unavoidable despite coping strategies such as diversification of sources of raw materials. The smallholders are inherently not able to cope with stringent quality demands posed by the globalised market in addition to difficulties to cope with all associated risks. In and of themselves, these aspects become significant barriers to entry into the high value chain. The study of enabling environments is thus significant especially with a focus on the highly vulnerable subsectors such as the smallholder farming community. The objective of this current study was therefore, to assess the enabling environment for the horticultural crops value chain for purposes of informing identification of critical mechanisms to foster core competences needful for the subsector to proactively participate in the main value chain system. In turn, this will inform on how the smallholders can best position themselves in the market place. This study however, acknowledges that the components of the enabling environment considered here may not be exhaustive but are nonetheless relevant and necessary to unearth the general conditions promoting or hampering the performance of the smallholder farming subsector and its vulnerability to exclusion from the mainstream value chains.

\section{Materials and Methods}

The conditions that favour or hamper the investment attractiveness of a particular economic sector in a given economy may not be similar to those that are important for other sectors (Konig et al., 2013). This makes it imperative to consider business environments from a sector-based perspective. This also applies to sub-sectors within a given sector in this instance, the smallholder farming subsector of the agricultural industry. Different subsectors differ widely in their characteristics with certain factors and conditions impacting differently and with varying degrees on specific sectors. This study made use of structured questionnaires to collect primary data from 56 smallholder farmers in Gauteng Province of South Africa that are specialising in the production of vegetables for the market as well as those that produce sellable excess vegetables. The choice of the farmers was a complete list of smallholder producers of vegetables earmarked for the market that was provided by the Gauteng Department of Agriculture and Rural Development (GDARD). This group forms the largest part of the farming community engaged in commercial production within the province. Six vegetables (tomatoes, mutshaina, Choumoellier, kale, peppers and chillies) were selected for this study.

While the study of the value chain analysis takes into account all the three inter-linked components of the market map viz, value chain actors, enabling environment and service providers (Figure 1), the current study focused only on the enabling environment. The assessment of the enabling environment focused on exploring the business-friendly conditions that are and/or need to be in place in order to drive the smallholder farming vigour. Three critical elements of the enabling environment were considered, namely, the basic requirements, efficiency enhancers and useful enablers. This study used descriptive statistics to analyse some of the elements of the enabling environment. A Likert Scale of between 1 (strongly disagree) and 5 (strongly agree) was used to rank farmers' perceptions of the pre-coded factors. Binary logistic regression was run to predict the determinants of the type of market utilized by the farmers. The independent variables included such factors as demographic data, sources of market information, the presence of youths within the project as well as engagement in some value addition activity within the farm among others. The model is specified as follows:

$$
Y=\beta_{0}+\beta_{1} X_{1}+\beta_{2} X_{2}+\ldots+\beta_{k} X_{k}+\varepsilon
$$

Where,

$Y=$ is the binary response variable ( $Y_{i}=1$ for formal market access, and $Y_{i}=0$ for informal market access); $\beta_{0}$ $=$ is the intercept; $\beta=\left(\beta_{1}, \beta_{2}, \ldots \beta_{k}\right)$ are the coefficients; $X=\left(X_{1}, X_{2} \ldots X_{k}\right)$ is a set of the explanatory variables; $\varepsilon$ is the error term.

The summary of findings of this study is discussed in the subsequent section.

\section{Results and Discussion}

Table 1 presents the demographic information of the population under study. The middle aged (35-64 years) were more than $(44.6 \%)$ the youth $(23.2 \%)$ and aged farmers $(32.1 \%)$. Female farmers were more $(55.4 \%)$ than their male compatriots (44.6\%). Half of the population had attained secondary level of education while the holders of primary and tertiary levels of education were $39.3 \%$ and $10.7 \%$ respectively. The majority of the farmers $(64.3 \%)$ operate as cooperatives, $28.6 \%$ as family-owned farming operations while $7.1 \%$ operated as registered companies. While communal land ownership systems are a commonplace, it is important to note that 
any forms of insecure land tenure have been proven a disincentive to the implementation of long-term developments that demand huge capital resources.

Table 1. Demographic variables

\begin{tabular}{lll}
\hline Demographic Variables & Actual number & $\mathbf{\%}$ \\
\hline Age (Years) & 13 & \\
$27-34$ & 25 & $23.2 \%$ \\
$35-64$ & 18 & $44.6 \%$ \\
$65-86$ & 56 & $32.1 \%$ \\
Total & & $100 \%$ \\
\hline Gender & 31 & \\
Female & 25 & $55.4 \%$ \\
Male & 56 & $44.6 \%$ \\
Total & & $100 \%$ \\
\hline Level of education & 0 & $0 \%$ \\
Illiterate & 22 & $39.3 \%$ \\
Primary & 28 & $50.0 \%$ \\
Secondary & 6 & $10.7 \%$ \\
Tertiary & 56 & $100 \%$ \\
Total & & \\
Type of business & 16 & $28.6 \%$ \\
Family owned & 36 & $64.3 \%$ \\
Cooperatives & 4 & $7.1 \%$ \\
Registered business & 56 & $100 \%$ \\
Total & & \\
\hline
\end{tabular}

The findings of this study categorised the elements of the enabling environment into three classes that promote efficient development and operation of market-based competition, namely; basic requirements, efficiency enhancers and useful enablers. The basic requirements are the fundamental essentials. Efficiency enhancers provide support for the fundamentals in ensuring a properly functioning marketing system. Useful enablers create powerful opportunities for inclusive value chain operations through shaping business costs, risks and, ultimately business competitiveness (Webber, 2017). Table 2 shows the most compelling components of the enabling environment that were rated by the farmers on a Likert Scale of 1 to 5, with 1 indicating least compelling and 5 indicating more critical within their respective categories. Two extreme points were developed to align the results of the analysed Likert Scale findings with 'necessary conditions' indicating those that ranked high ( $\geq 4$ average) and the 'sufficient conditions' representing those that ranked lower $(1 \leq$ score $\geq 3)$. The elements that had an average score ranging between 3.1 and 3.9 are presented as 'intermediate enablers' (Table 2). The Table presents the challenging business environmental elements in respect of the degree to which they impede performance based on the score values attached to each element by the respondents. A few of these elements are further discussed in detail in subsequent sections regarding the manner in which they affect the performance of the farmers. It is therefore, anticipated that developments and investments in these environmental aspects will lead to improvements in conditions of business competitiveness. The improvements may also impact change in society as a whole resulting from multiplier effects. 
Table 2. Enabling environment for farmer competitiveness

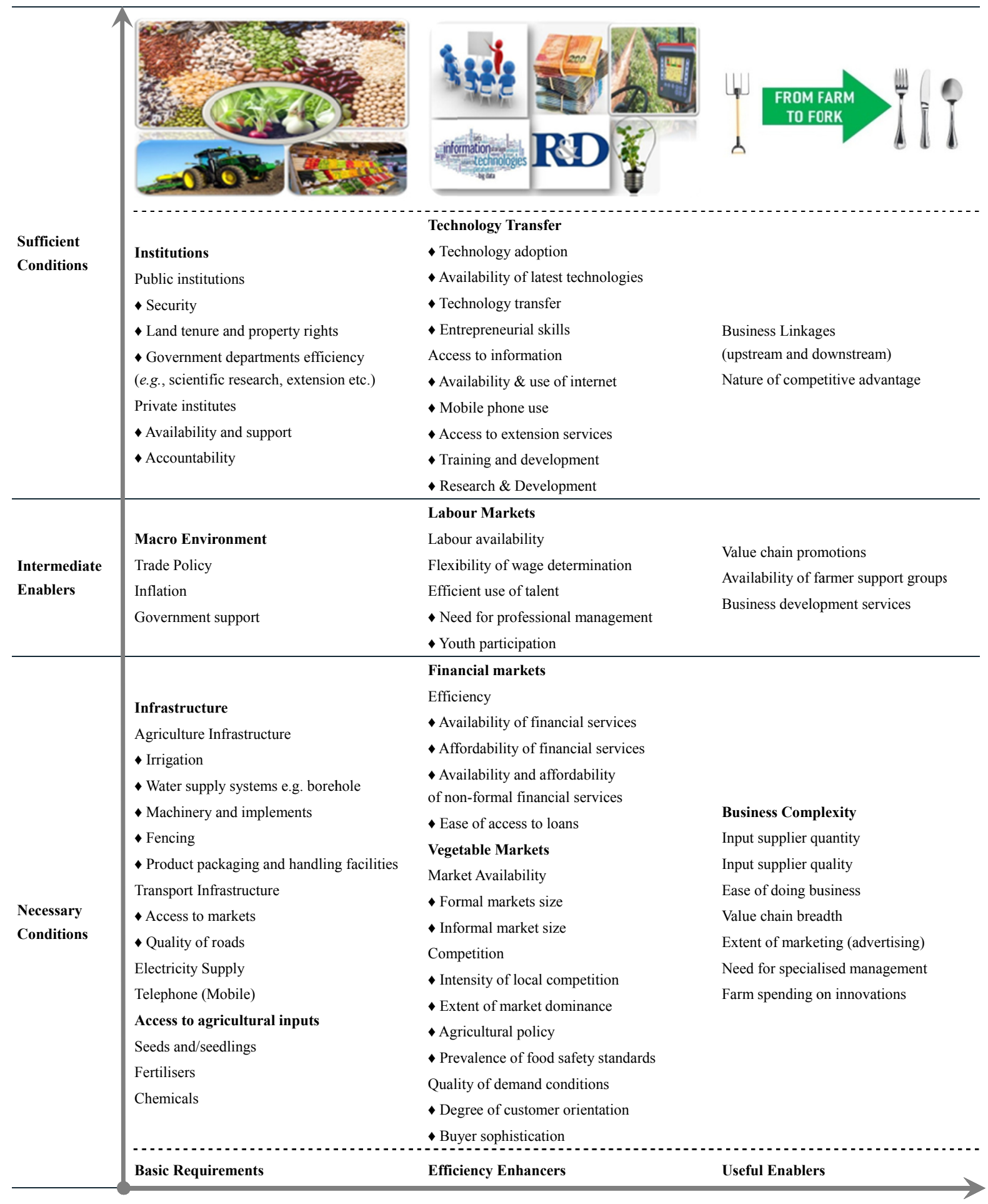

Coupled with physical observations, the farm surveys revealed that there are many infrastructural needs for the farmers ranging from farm machinery or implements to buildings. Some shade nets were very old, tattered, and torn. In addition, infrastructure such as storage facilities and cold rooms were lacking in some farms where production levels of vegetables would warrant such handling facilities. Some access roads limited access to input and product markets. In response to access to irrigation system, $10.3 \%$ relied strictly on rainfall for their agricultural activities. Lack of irrigation means that their production is strictly confined to rainy seasons. 


\subsection{Access to Product Markets}

Table 3 indicates the vegetable production levels, marketing and losses incurred. The largest quantities of vegetables were marketed through informal markets with the exception of tomatoes and peppers. Most of the sales transactions were conducted at the farm-gate (59\%), while the rest used both the farm-gate and marketing stalls.

Table 3. Analysis of vegetables production, marketing and losses incurred

\begin{tabular}{|c|c|c|c|c|c|c|c|c|}
\hline Vegetable Type & Total Produced & Market supplied & Quantity Sold & $\begin{array}{l}\text { Quantity } \\
\text { consumed }\end{array}$ & $\begin{array}{l}\text { Quantity } \\
\text { Losses }\end{array}$ & $\begin{array}{l}\text { \% Home } \\
\text { consumed }\end{array}$ & $\begin{array}{c}\text { Ave \% } \\
\text { Losses }\end{array}$ & $\begin{array}{l}\text { Max \% } \\
\text { Loss }\end{array}$ \\
\hline Kale & 26958 (Bundles) & $\begin{array}{l}\text { Formal } \\
\text { Informal }\end{array}$ & $\begin{array}{l}5460 \\
18090\end{array}$ & 1629 & 1779 & $6.0 \%$ & $6.6 \%$ & $60 \%$ \\
\hline Choumoellier & 14119 (Bundles) & Formal & $\begin{array}{l}1842 \\
11315\end{array}$ & 532 & 430 & $3.8 \%$ & $3.0 \%$ & $10 \%$ \\
\hline Mutshaina & 14576 (Bundles) & $\begin{array}{l}\text { Formal } \\
\text { Informal }\end{array}$ & $\begin{array}{l}1042 \\
11861\end{array}$ & 989 & 684 & $6.8 \%$ & $4.7 \%$ & $88.2 \%$ \\
\hline Peppers & 9158,45 (Crates) & $\begin{array}{l}\text { Formal } \\
\text { Informal }\end{array}$ & $\begin{array}{l}6099,2 \\
3310\end{array}$ & 187 & 562.25 & $2.0 \%$ & $6.1 \%$ & $88.2 \%$ \\
\hline Tomatoes & 11125,5 (Crates) & $\begin{array}{l}\text { Formal } \\
\text { Informal }\end{array}$ & $\begin{array}{l}7408 \\
2177\end{array}$ & 518.5 & 1022 & $4.7 \%$ & $9.2 \%$ & $88.5 \%$ \\
\hline Chillies & 1597 (Packets) & Informal & 1099.25 & 40.35 & 71 & $2.5 \%$ & $4.4 \%$ & $16.7 \%$ \\
\hline
\end{tabular}

Note. * A bundle is equivalent to $550 \mathrm{~g}$, Crate is $+/-9 \mathrm{~kg}$, and a packet is the equivalent of $500 \mathrm{~g}$ plastic.

The binary logistic regression was run to establish the determinants of the type of market accessed and utilised by the farmers. The results (Table 4) show a positive association between the choice of most utilised market and age, level of education, already arrangement with certain markets and sources of information on markets. Value addition did not have an association with accessing markets.

Table 4. Determinants of choice of markets

\begin{tabular}{|c|c|c|c|c|c|c|c|c|}
\hline & \multirow{2}{*}{$\mathrm{B}$} & \multirow{2}{*}{ S.E. } & \multirow{2}{*}{ Wald } & \multirow{2}{*}{$\mathrm{df}$} & \multirow{2}{*}{ Sig. } & \multirow{2}{*}{$\operatorname{Exp}(B)$} & \multicolumn{2}{|c|}{$95 \%$ C.I. for $\mathrm{EXP}(\mathrm{B})$} \\
\hline & & & & & & & Lower & Upper \\
\hline Age & .132 & .046 & 8.228 & 1 & .004 & 1.142 & 1.043 & 1.250 \\
\hline Gender & 2.729 & 1.478 & 3.408 & 1 & .065 & 15.315 & .845 & 277.528 \\
\hline Education & 5.134 & 1.642 & 9.781 & 1 & .002 & 169.668 & 6.797 & 4235.362 \\
\hline Production plan & .630 & 1.123 & .315 & 1 & .575 & 1.878 & .208 & 16.982 \\
\hline Youths involved & -1.506 & 1.180 & 1.630 & 1 & .202 & .222 & .022 & 2.240 \\
\hline Formal agreement with markets? & 2.892 & 1.301 & 4.941 & 1 & .026 & 18.037 & 1.408 & 231.077 \\
\hline Knowledge of price & 18.168 & 15593.737 & .000 & 1 & .999 & 77667978.597 & .000 & .000 \\
\hline Sources of market information & 1.706 & .584 & 8.524 & 1 & .004 & 5.504 & 1.752 & 17.296 \\
\hline Involvement in value addition & 2.113 & 1.088 & 3.771 & 1 & .052 & 8.274 & .981 & 69.822 \\
\hline Constant & -68.189 & 31187.475 & .000 & 1 & .998 & .000 & & \\
\hline
\end{tabular}

Kale recorded the highest produce losses among the leafy vegetable that include Choumoellier and Mutshaina. Produce losses take place along the entire supply chain. However, this study records only those losses incurred at the production fields, the losses incurred on transit to the markets and those delivered to NFPMs but could not be sold, and farmers would be asked to collect their produce. The quantities were estimated based on edible and sellable vegetables whose quantities were actually recorded. Crop losses at field level were estimated based on easily identifiable field level crop damages caused by drought, weeds, insect pests, plant diseases and stray animals. Losses on transit to markets and those rejected at market level were based on estimates given by farmers where harvesting and marketing has been in process for a while before the survey. The average losses may seem low but it is important to note that in general food losses get as high as $40 \%$ when the entire supply chain is analysed (Johnson et al., 2018). It is critical to note that for certain farms the losses were as high as $88 \%$. The 
farmers with the highest produce losses had challenges of accessing markets. However, for Kale it was solely a result of consumer familiarity with the crop in addition to limited markets for the vegetable. This indicates the high need for assisting the farmers that are currently producing for the informal markets to gain access and recognition in formal markets including promotion of the vegetables. The produce that failed to go through to the markets (the unsellable produce) was either donated (46.2\%), thrown away (12.8\%), home consumed (2.6\%), fed to animals $(5.1 \%)$ or processed $(2.6 \%)$. Food product losses are a representation of wasted water, physical and financial inputs, labour and land. These losses negatively affect producer incomes.

Table 5 shows the average prices offered by different types of markets for the different vegetables. Kale, Choumoellier and Mutshaina are largely consumed by the informal market and unexpectedly, that is where the producers fetch the highest prices. In respect to these three leafy vegetables, the smallholder farmers will better dispose off their produce through the informal markets for higher financial returns. Surveys unveiled that Kale and Choumoellier are not very popular vegetables and their main consumers are those who have a previous experience with them mainly foreign nationals. The promotion of these vegetables both at production and consumption levels has potential not only to promote nutritional security but also the income generation for their producers. All the other vegetables have their highest per unit prices offered by the formal markets and thus, giving the producers better financial returns there.

Table 5. Variations in vegetable prices according to markets

\begin{tabular}{|c|c|c|c|c|c|}
\hline Vegetable & Type of Market & Standard Unit * & Max Price & Min Price & Ave Price \\
\hline \multirow{2}{*}{ Kale } & Formal & Bundles & $\mathrm{R} 8.50$ & R5.00 & R6.75 \\
\hline & Informal & bundles & $\mathrm{R} 15.00$ & R5.00 & $\mathrm{R} 8.56$ \\
\hline \multirow{2}{*}{ Choumoellier } & Formal & bundles & R9.00 & R9.00 & $\mathrm{R} 9.00$ \\
\hline & Informal & bundles & R20.00 & $\mathrm{R} 3.50$ & $\mathrm{R} 8.60$ \\
\hline \multirow{2}{*}{ Mutshaina } & Formal & bundles & $\mathrm{R} 8.50$ & R5.00 & R6.75 \\
\hline & Informal & bundles & R15.00 & R5.00 & $\mathrm{R} 8.56$ \\
\hline \multirow{2}{*}{ Peppers } & Formal & Crates & R150.00 & R35.00 & R53.75 \\
\hline & Informal & Crates & $\mathrm{R} 120.00$ & R25.00 & R21.42 \\
\hline \multirow{2}{*}{ Tomatoes } & Formal & Crates & $\mathrm{R} 200.00$ & R70.00 & R116.00 \\
\hline & Informal & Crates & R120.00 & $\mathrm{R} 25.00$ & R46.05 \\
\hline \multirow{2}{*}{ Chillies } & Formal & Packets & $\mathrm{R} 75.00$ & $\mathrm{R} 75.00$ & $\mathrm{R} 75.00$ \\
\hline & Informal & Packets & R35.00 & R5.00 & R12.25 \\
\hline
\end{tabular}

Note. * A bundle is equivalent to $550 \mathrm{~g}$, Crate is $+/-9 \mathrm{~kg}$, and a packet is the equivalent of $500 \mathrm{~g}$ plastic.

The farmers were asked to indicate their preferred market and $62.2 \%$ indicated the formal market as their preference because the formal markets handle large quantities leading to the minimisation of product losses, better financial returns, constant and reliable cash flows, reliability and good product prices. Twenty-nine percent (29.7\%) preferred informal markets because of daily cash receipts as consumers walk in daily, no problems of selling produce in small quantities, limited transport expenses as street vendors and community-based consumers walk-in to buy the produce at the farm-gate and no handling costs (Table 6). For the leafy vegetables such as Kale, Choumoellier and Mutshaina, the informal market had better price offers at certain instances. However, $8.1 \%$ preferred the utilisation of both markets as both have different but complimentary demands, and thus eliminating high chances of product losses.

Table 6. Vegetable market preference

\begin{tabular}{ll}
\hline Preferred Market & Proportion of farmers \\
\hline Formal Market & $62.2 \%$ \\
Informal Market & $29.7 \%$ \\
Both Formal and Informal Markets & $8.1 \%$ \\
\hline Total & $\mathbf{1 0 0 \%}$ \\
\hline
\end{tabular}

Note. $\mathrm{n}=56$. 
Generally, the availability of markets should not be a problem for producers situated in Gauteng Province, as four of the 19 National Fresh Produce Markets (NFPMs) in South Africa are located in the province. The Gauteng NFPMs (Johannesburg, Tshwane, Springs and Vereeniging) deal in about $75 \%$ of the national fresh produce supply. Johannesburg and Tshwane NFPMs represent the first and second largest markets in South Africa, respectively. Apart from the NFPMs, there are many more (formal and informal) traders involved in selling fresh fruits and vegetables. The formal traders of fresh produce include retail shops (such as Pick n Pay, Spar, Shoprite/Checkers, Woolworths, Food Lover's Market, Boxer), Housewife markets, and green groceries (NDA, 2001). Generally, the high population density in Gauteng offers a stable and lucrative market for horticultural commodities, especially for fresh fruits and vegetables. The only impeding element to accessing these markets can be the failure of the smallholders to meet the standard stipulations set by the formal markets. This is supported by the findings of the views of the farmers about the standards set by the supermarkets. Approximately $89.7 \%$ of the farmers rated that the quality standards requirements by the formal markets are strict $(56.4 \%$ strict and $33.3 \%$ very strict). This is an indication that smallholder farmers have challenges in meeting the minimum quality demands set by high value chain markets despite the availability of the markets.

\subsection{Access to Information}

Access to information is a critical aspect in farming, most especially when production is aimed at channelling the produce into the formal markets. Access to information ensures profitable engagements of the farmers with the markets as this strengthens dissemination of information on markets and market prices as well as product quality standards requirements for various markets. More than half of the farmers $(51.3 \%)$ revealed that they conduct their own research, $23.1 \%$ rely on traders, $15.4 \%$ rely on other farmers while $10.3 \%$ indicated that they get assistance from the national department of agriculture for information about markets. The need for strengthening of the gathering and dissemination of market information among smallholder farming community is thus evident. The ability to use such information by the farmers is also another aspect that has to be established and reinforced. Although some processes and activities may be labour-intensive and add to costs, access to the exhaustive list on minimum requirements is important for informed decisions by smallholder farmers. For instance, value addition activities such as cleaning and pre-packaging, especially for peppers (rainbow range - red, yellow, green in a single pack), were discovered to be a preference of some supermarkets. This can be convenient for the farmers to be prepared to sell to markets that offer them better financial returns.

Of equal weight is the need for capacitation through formal and informal training. Ninety four percent (94.9\%) of the farmers reported that they received agricultural-related training in the past three years. Figure 2 presents the number of farmers (or farms) that received training for each of the subjects that the respondents indicated to have received training. The subjects included and were not limited to basic agriculture, crop production, financial management, hydroponics and conflict management. The highest number (15) received training on field crop production and irrigation. Production practices entailed such topics as crop rotation, seedbed preparation, fertilisation and harvesting. Post-harvest handling included such topics as food processing and packaging while farm management involved book keeping and budgeting. Vegetable specific training was not reported although the target smallholders in this study specialised largely in vegetable production. Despite the numerous farms with tunnels, only one farm recorded training in production under tunnels. It is important to note that business management, although critical for production for the market, it has received minimum attention in terms of the number of people trained. However, it is important to note that not all of the farmers received similar forms of subject matter or course in training. More so, by and large, the training was a once-off service. 


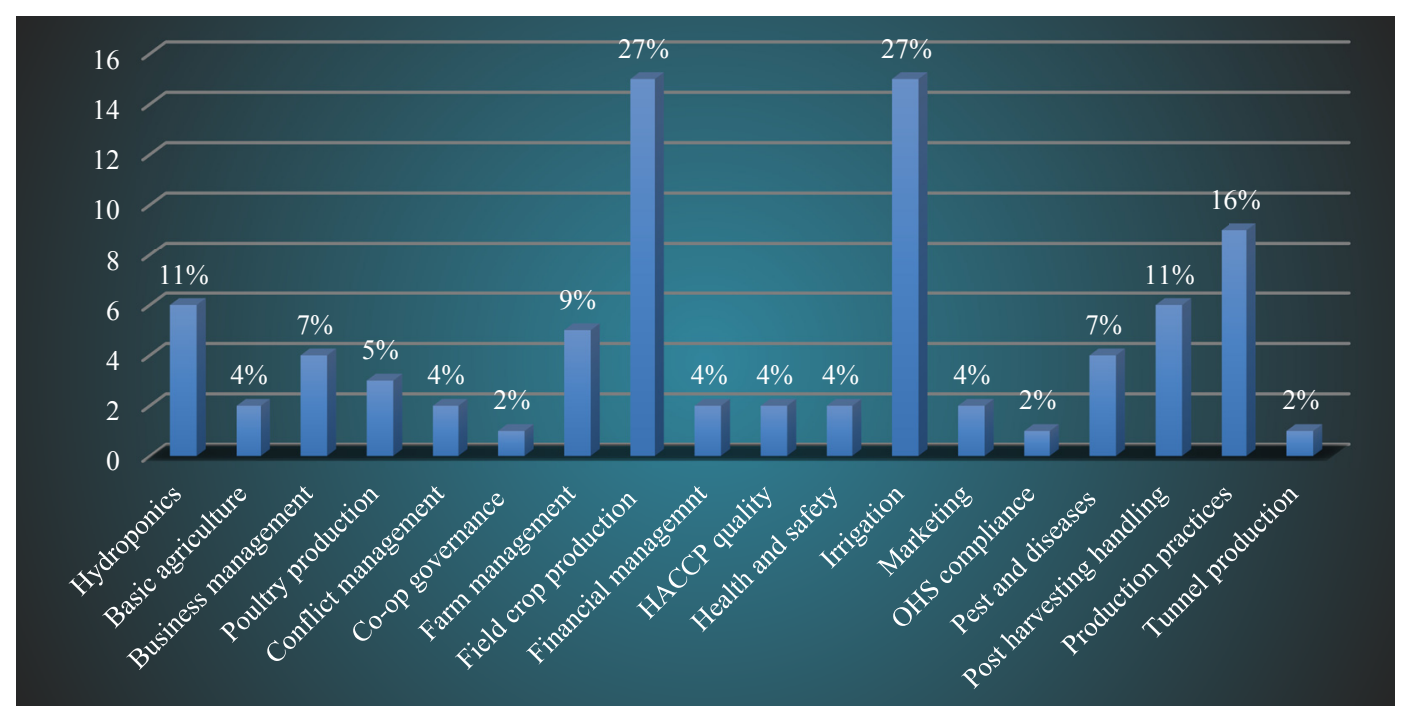

Figure 2. Number of farm(er)s trained in each course

\subsection{Access to Finance}

Agricultural financing is one of the most important drivers to development particularly in the rural sectors of developing countries. While smallholders inherently lack finance for their farming activities, access to credit finance and/or grants lessen the problem, thereby promoting increased productivity. Table 4 shows the various sources of finance utilised by smallholder farmers in Gauteng Province to fund their agricultural activities. It is important to note that most of these sources of finance are informal. Government assistance was in the form of input handouts and grants that tended to cushion the challenges of poor financing of the smallholder agricultural activities. A larger proportion (41\%) of the farmers depended on own savings to finance the agricultural activities (Table 7). Eighteen percent (18\%) depended on previous seasons' sales revenue to finance their production. A small proportion (3\%) managed to secure loans for their farming activities. This is critical to note, as all of the surveyed farmers were fulltime farmers with small landholdings of up to 2 hectares maximum. Incentivising farmers in taking riskier but more profitable investments where circumstances permit such a move has been advocated for in many instances (Karlan et al., 2012b; Mobarak \& Rosenzweig, 2012; Xavier et al., 2010). Carter (2008) however, proposed that the intervention should be simplified to target the most important part of the risk faced by the farmers. Record keeping among the smallholders will thus be supportive for the individual farmer performance, making risk calculation a lot more easier (World Bank, 2007). However, since provision of finances increases the probability of increased production finance should be considered in light of access to formal markets.

Table 7. Source of finance and/or credit

\begin{tabular}{ll}
\hline Source of finance & Proportion of farmers utilising source \\
\hline Contributions from project members & $5 \%$ \\
Get contracts from Social Development & $3 \%$ \\
Government assistance & $8 \%$ \\
Loan & $3 \%$ \\
Own savings & $41 \%$ \\
Own savings + Government assistance & $11 \%$ \\
Own savings + Previous sales & $8 \%$ \\
Previous season sales & $18 \%$ \\
Sibanye Still Water & $3 \%$ \\
\hline Grand Total & $\mathbf{1 0 0 \%}$ \\
\hline
\end{tabular}




\subsection{Access to Input Markets}

An evaluation of the sources of inputs that the smallholder farmers utilised indicated that $41.7 \%$ relied on government handouts especially seeds mainly from the Provincial Department of Agriculture. The majority of those that received input handouts exclusively relied on these and did not supplement in any form. Some farmers however, suffered limited choices of suppliers to choose from, thus basing their utilisation of suppliers on reasons such as closest supplier (19.6\%), only supplier known (7.4\%), the availability of inputs in smaller packs (7.4\%) while $6.1 \%$ were referred to suppliers (Table 8). This invites the need to make information and database of input suppliers available to the farmers to aid informed comparison of price variations for savings and the nature of services the various suppliers can offer beyond the input.

Table 8. Reason for utilising input suppliers

\begin{tabular}{ll}
\hline Reason for utilising suppliers & Proportion of respondents \\
\hline Availability of small packs & $7.4 \%$ \\
Cheaper & $4.3 \%$ \\
Closest supplier & $19.6 \%$ \\
Free handouts & $41.7 \%$ \\
Difficult to get seeds in local retail shops & $3.1 \%$ \\
Only supplier known & $7.4 \%$ \\
Credit facility-Pay for inputs after sales & $0.6 \%$ \\
Referred & $6.1 \%$ \\
Reputable for good quality & $8.0 \%$ \\
Sells in large quantities & $1.8 \%$ \\
\hline Grand Total & $\mathbf{1 0 0 . 0 \%}$ \\
\hline
\end{tabular}

\section{Conclusions and Recommendations}

The study showed a number of challenges faced by smallholder including limitations to access markets, infrastructure, access to finance, access to information and capacity building. Funding should be tailor-made for critical systems and aspects of the chain management especially the promotion of productivity, product quality and meeting quality specifications outlined by high value markets. The government is already doing wonderfully well in providing support for these farmers through farm inputs. However, these are not a multipurpose solution to exclusive performance of smallholders in high value chain systems. Policy makers should find and prioritise strategies towards reduction of exposure to risk by smallholders, with a highly likely probability to create a more enabling environment for all value chain players to engage with smallholder farmers.

Farmers indicated that they received training in various agricultural topics. The study however, showed that much of the courses offered to the average farmer were not in direct sync with the enterprises practiced within the farms. Technical advisory services should be entrenched in all the interventions to promote growth of smallholder farmers within their trade or particular enterprises. Institutions working with and supporting farmers need to provide relevant training that matches the production focus of the farmers that they are supporting. Other subjects and training focus can be as subsidiary and support content to foster the major focus of the farm objectives. Where opportunities for capacity development are available for smallholder farmers, there is need for a match between the opportunities and the enterprises of interest together with the resources for improved active participation by the smallholders in the value chain. Development agents need to be articulate and responsive to the demands of the smallholders in the face of opportunities in the agricultural value chain.

A significant number of smallholder farmers depend on own savings to finance their agricultural production activities. This is likely to be a huge challenge as the farmers experience product losses where all the sellable vegetables do not always get sold, and thus income from the sales might not be enough to offset the production costs. Smallholder farmer financing and access to credit need to be promoted. However, access to finance should be done synchronously with access to formal markets, as the likelihood of increased production increases with proper financing. Incentivising farmers in taking riskier but more profitable investments where circumstances permit is recommended. These should be backed by technological support as well as proper risk management strategies. The support of the Agricultural Advisors that work daily with the farmers will be very convenient for 
the success of this intervention. Access to both product and input markets will therefore need to be strengthened to curb product losses while maximising the best income returns for the farmers.

The not-so-common leafy vegetables (Kale and Choumoellier) fetched high prices in the informal markets compared to the formal markets. Although the informal markets are not always able to consume increased vegetable volumes resulting from increased production, they still remain relevant for selling vegetables produced by smallholder farmers. There is however, a need to support and promote the production and marketing of these vegetables through formal value chains. Sufficient returns on investments still remain a prerequisite for any improvements made to the business environment. The choice of market utilised by the farmers is influenced by the age and level of education of the farmers. Established marketing arrangements to deliver vegetables to certain markets and sources of information on markets influence the utilisation of formal markets.

In conclusion, the government through its various departments and policy frameworks, should facilitate the ability of the smallholder farmers to access finance, access product markets, avail mentorship systems to capacitate farmers through skills development on compliance with market standards. The retailers have the expertise, the network and accountability, while the government has the money to facilitate such engagements. Despite the nation's good agricultural policies that aim at uplifting the smallholder farming subsector, identification of fundamental elements of the enabling environment that are influential to an inclusive value chain is critical to highlight. The problems that may hamper the translation of policy and challenges faced by smallholders from paper to actual effecting need special and continual attention.

Public-private partnerships should be strengthened around the prioritised agenda of improving the enabling environment. Bringing together partners to develop national market information systems using technology such as mobile phones can be convenient in curbing the challenges of limited access to information of markets. Multi-stakeholder engagements are vital in farmer support for purposes of avoiding overlaps and thereby increasing scope of support and number of beneficiaries. The pooling of a wide range of implementing partners merges the resources to be tapped into, coupled with proper channelling as needs-based assessments with reveal. This will focus towards improved inclusive activity by smallholder within the mainstream value chain. This may include the harmonisation of the several initiatives by different organisation, although the challenge of vested interests may not be ruled out as a possible impediment. Special assistance tailor-made for the smallholder subsector should include deploying a critical multi-disciplinary team of expertise to assess the environment such that any interventions addresses relevant problems for each case scenario. The Department of Agriculture and Rural Development is well positioned to play a leadership role in multi-stakeholder engagement.

\section{References}

Carter, M. (2008). Inducing Innovation: Risk Instruments for Solving the Conundrum of Rural Finance. Keynote paper prepared for the Agence Francaise de Developpement and European Development Network's 6th Annual Conference, November 12, 2008, Paris, France.

Christy, R., Mabaya, E., Wilson, N., Mutambatsere, E., \& Mhlanga, N. (2009). Enabling environments for competitive agro-industries. In C. da Silva, A. W. D. Baker, C. J. Shepherd, \& S. M. da Cruz (Eds.), Agro-industries for development (pp. 136-185). Wallingford, UK. https://doi.org/10.1079/97818459357 64.0136

Feed the Future. (2017). The US Government's Global Hunger and Food Security, 2017. Building an Enabling Environment for Agricultural Transformation and Market Development Global Learning and Evidence Exchange-Market Systems. Bangkok, Thailand.

Johnson, K. L., Dunning, R. D., Bloom, D. J., Gunter, C. C., Boyette, M. D., \& Creamer, N. G. (2018). Estimating on-farm food loss at the field level: A methodology and applied case study on a North Carolina farm. Resources, Conservation and Recycling, 137, 243-250. https://doi.org/10.1016/j.resconrec.2018. 05.017

Karlan, D., Osei-Akoto, I., Osei, R., \& Udry, C. (2012a). Examining Underinvestment in Agriculture: Measuring Returns to Capital and Insurance Among Farmers in Ghana. J-PAL, USA.

Karlan, D., Osei-Akoto, I., Osei, R., \& Udry, C. (2012b). Agricultural Decisions after Relaxing Credit and Risk Restraints (Unpublished working paper, Yale University, New Haven, CT). https://doi.org/10.3386/w18463

Konig, G., da Silva, C. A., \& Mhlanga, N. (2013). Enabling environments for agribusiness and agro-industries development: Regional and country perspectives (Agribusiness and Food Industries Series 1). Food and Agriculture Organization of the United Nations, Rome. 
Llanto, G. M. (2012). The Impact of Infrastructure on Agricultural Productivity (Discussion Paper DP 2012-12). Philippine Institute of Development Studies, Philippine.

Louw, A., Vermeulen, H., Kirsten, J., \& Madevu, H. (2007). Securing small farmer participation in supermarket supply chains in South Africa. Development Southern Africa, 24(4), 539-551. https://doi.org/10.1080/037 68350701577657

Mobarak, A., \& Rosenzweig, M. (2012). Selling Formal Insurance to the Informally Insured (Economics Department Working Paper 97, Yale University, New Haven, CT). https://doi.org/10.2139/ssrn.2009528

Muchopa, C. L. (2013). Agricultural value chains and smallholder producer relations in the context of supermarket chain proliferation in Southern Africa. International Journal of Value Supply Chain Management, 4(3), 33-44. https://doi.org/10.5121/ijmvsc.2013.4304

Neven, D. (2015). Three steps in value chain analysis (MicroNote 3). Publication produced for review by U.S. Agency for International Development. Retrieved June 28, 2018, from https://www.marketlinks.org/ sites/default/files/resource/files/mn_53_three_steps_in_vc_analysis.pdf

von Loeper, W. J., Drimie, S., \& Blignaut, J. (2018). The Struggles of Smallholder Farmers: A Cause of Modern Agricultural Value Chains in South Africa. Agricultural Value Chain. Gokhan Egilmez, IntechOpen. https://doi.org/10.5772/intechopen.75710

von loeper, W. J., Musango, J. K., Brent, A., \& Drimie, S. (2016). Analysing challenges facing smallholder farmers and conservation agriculture in South Africa: A system dynamics approach. South African Journal of Economic and Management Sciences, 19(5), 747-773. https://doi.org/10.4102/sajems.v19i5.1588

Vorley, B., Fearne, A., \& Ray, D. (2007). Regoverning markets: A place for small-scale producers in modern agri-food chains? Gower Publishing, UK.

Webber, M. (2017). Governance issues and public institutional support. In E. G. Nogales \& M. Webber (Eds.), Territorial tools for agro-industry development: A sourcebook (pp. 313-355). Food and Agriculture Organisation of the United Nations, Rome, Italy.

World Bank. (2007). World Development Report 2008: Agriculture for Development. Washington, DC: World Bank. https://doi.org/10.1596/978-0-8213-6807-7

Xavier, G., Jakiela, P., Karlan, D., \& Morduch, J. (2010). Microfinance Games. American Economic Journal: Applied Economics, 2(3), 60-95. https://doi.org/10.1257/app.2.3.60

\section{Copyrights}

Copyright for this article is retained by the author(s), with first publication rights granted to the journal.

This is an open-access article distributed under the terms and conditions of the Creative Commons Attribution license (http://creativecommons.org/licenses/by/4.0/). 